\title{
HUBUNGAN KUALITAS AIR BRSIH TERHADAP TINGKAT KEPUASAN KONSUMEN PADA PDAM TIRTA BINA RANTAUPRAPAT LABUHANBATU
}

\author{
Bayu Eko Broto
}

Dosen Tetap Sekolah Tinggi Ilmu Ekonomi (STIE) Labuhanbatu

\begin{abstract}
Abstrak:
Penelitian ini bertujuan untuk mengetahui apakah terdapat hubungan yang signifikan antara kualitas air bersih terhadap tingkat kepuasaan konsumen pada PDAM Tirtabina Rantauprapat Labuhanbatu. Teknik pengumpulan data yang digunakan dalam penelitian ini adalah angket tertutup dan dokumentasi. Dalam penelitian ini jumlah populasinya seluruh pelanggan PDAM Tirta Bina Rantauprapat Labuhanbatu yang berjumlah 7060 orang. Sedangkan sampel dalam penelitian ini diambil dengan menggunakan rumus Slovin maka sampelnya diambil sebanyak 99 orang responden.Teknik analisa datayang digunakan dalam penelitian ini adalah Teknik Koefisien Korelasi Product Moment.Hasil analisis uji korelasional dari rumus koefisien korelasi produk moment yang digunakan dalam penelitian ini diperoleh indek koefisien korelasi hitung $\left(r_{h}\right)$ sebesar 0,617 pada taraf signifikan 95\%, taraf nyata 5\% dan tergolong kedalam kategori korelasi kuat. Sedangkan indeks koefisien korelasi tabel $\left(r_{\text {tab }}\right)$ sebesar 0,202. Hal ini berarti hipotesis yang menyatakan "Terdapat hubungan yang signifikan antara kualitas air bersih terhadap tingkat kepuasaan konsumen”, diterima, karena indek (harga) koefisien korelasi hitung $\left(r_{h}\right)$ lebih besar $>$ dari harga koefisien korelasi tabel $\left(r_{\text {tab }}\right)$ yakni 0,617<0,202. Sedangkan pengujian hipotesis digunakan untuk mengetahui apakah terdapat hubungan yang signifikan antara kualitas air bersih terhadap tingkat kepuasaan konsumen pada PDAM Tirtabina Rantauprapat Labuhanbatu maka dilakukan dengan pengujian hipotesis dengan menggunakan Uji keberartian dengan statistik $t$ diperoleh hasil thitung $>t_{\text {tabel }}$ yaitu 7,721 > 1,660. Oleh karena itu Ho ditolak dan Ha diterima, sehingga dapat ditarik kesimpulan "terdapat hubungan yang signifikan antara kualitas air bersih terhadap tingkat kepuasaan konsumen pada PDAM Tirtabina Rantauprapat Labuhanbatu”. Persentase hubungan antara kualitas air bersih terhadap tingkat kepuasaan konsumen pada PDAM Tirtabina Rantauprapat Labuhanbatu dilakukan dengan menguji koefisien determinasi sebagai berikut: $D=r_{x y 2 x} 100 \%$ diperoleh hasil sebesar 38,07\%, sisanya 61,93\% (100-38,07) dipengaruhi oleh faktor lain.
\end{abstract}

Kata Kunci: $\quad$ Kualitas Air Bersih, Tingkat Kepuasaan Konsumen.

\section{Abstract:}


This study aims to determine whether there is a significant relationship between the quality of clean water to the level of customer satisfaction at Tirtabina Rantauprapat PDAM Labuhanbatu. Data collection techniques used in this study is a closed questionnaire and documentation. In this study, the total population of all PDAM Tirta Bina Rantauprapat subscribers of Labuhanbatu totaling 7060 people. While the sample in this study was taken by using Slovin formula then the sample was taken as much as 99 respondents. Data analysis technique used in this research is Product Moment Correlation Coefficient Technique. The result of correlation test analysis from the formula of correlation coefficient of product moment used in this research obtained correlation coefficient index count (rh) of 0.617 at significant level 95\%, 5\% real level and belonging to strong correlation category. While the correlation coefficient table (rtab) of 0.202. This means the hypothesis that "There is a significant relationship between the quality of clean water to the level of customer satisfaction", is accepted, because the index of the correlation coefficient ( $r h$ ) is greater than the price of the correlation coefficient table (rtab) ie $0.617<0.202$. While hypothesis testing is used to find out whether there is a significant relationship between the quality of clean water to the level of customer satisfaction in Tirtabina Rantauprapat PDAM Labuhanbatu then done by testing the hypothesis by using significance test with $t$ statistics obtained tcount> ttabel is 7,721> 1,660. Therefore Ho is rejected and Ha accepted, so it can be concluded "there is a significant relationship between the quality of clean water to the level of customer satisfaction in Tirtabina Rantauprapat Labuhanbatu". The percentage of relationship between the quality of clean water to the level of customer satisfaction in Tirtabina Tirta Rantaup Labuhanbatu PDAM done by testing the coefficient of determination as follows: $D=r_{-}(\llbracket x y \rrbracket \wedge 2 \times 100 \%)$ obtained results of $38.07 \%$, the remaining 61.93\% 100-38.07) is influenced by other factors.

Keywords:Quality of Clean Water, Consumer Satisfaction Level.

\section{PENDAHULUAN}

Salah satu nilai utama yang diharapkan oleh pelanggan dari produsen adalah kualitas produk dan jasa yang tertinggi. Kepuasan konsumen / pelanggan berhubungan dengan harapa dari pelanggan itu sendiri terhadap kualitas produk yang dirasakan.

Produk adalah segala sesuatu yang dapat ditawarkan di pasar, untuk memuaskan kebutuhan dan keinginan konsumen. Produk terdiri atas barang, jasa, pengalaman, events, orang, tempat, kepemilikan, organisasi, informasi, dan ide. Jadi produk itu bukan hanya berbentuk sesuatu yang tidak berwujud seperti pelayanan jasa.Semuanya diperun-tukkan bagi pemuas kebutuhan dan keinginan (need and want) dari konsumen.

Produsen harus memperhatikan kualitas produk yang akan dipasarkan karena apabila kualitas produk tersebut tinggi maka konsumen akan tidak merasakan kepuasan terhadap produk tersebut. Air bersih adalah produk yang harus dilihat dari kualitasnya, 
karna air bersih yang digunakan oleh konsumen, harus dapat memuaskan ke inginan konsumen, maka produsen harus menjaga kualitas air bersih, agar tidak mengecewakan para konsumen atau pelangganProdusen akan merasakan kepuasan apabila kebutuhanya, dan keinginanya dapat dipenuhi. Maka produk air bersih yg dipasarkan harus mempunyai kualitas yang tinggi dan memenuhi standart yang telah di sesuaikan. Sehingga konsumen tidak lagi ragu untuk menggunakan produk air bersih yang dipasarkan kepada konsuman/ pelanggan. Kualitas air bersih itu sebagai aspek utama yang harus dimiliki. Karena kualitas produk air bersih sebagai tolak ukur kepuasan konsumen secara langsung dan tidak langsung. Karena Kualitas produk air bersih sebagai salah satu yang membedakan dengan produk pesaingnya.

Penelitian Ini dilakukan bertujuan untuk menganalisis tentang hubungan kualitas air brsih terhadap tingkat kepuasan konsumen Pada PDAM Tirta Bina Rantauprapat Labuhanbatu.

Tinjauan pustaka dalam penelitian ini sebagai berikut:

Salah satu nilai utama yang diharapkan oleh pelanggan dari produsen adalah kualitas produk dan jasa yang tertinggi. Menurut American Society for Quality Control, kualitas adalah keseluruhan ciri serta sifat suatu produk atau pelayanan yang berpengaruh pada kemampuannya untuk memuaskan kebutuhan yang dinyatakan atau tersirat.

Menurut KotlerKualitas produk adalah kemampuan suatu barang untuk memberikan hasil / kinerja yang sesuai atau melebihi dari apa yang diinginkan pelanggan. Menurut Mullins, Orville, Larreche, dan Boyd (2005) apabila perusahaan ingin mempertahankan keunggulan kompetitifnya dalam pasar, perusahaan harus mengerti aspek dimensi apa saja yang digunakan oleh konsumen untuk membedakan produk yang dijual perusahaan tersebut dengan produk pesaing.

Menurut Tjiptono (2008), dimensi kualitas produk meliputi :

1) Kinerja (performance)

Yaitu karakteristik operasi pokok dari produk inti (core product) yang dibeli, misalnya kecepatan, konsumsi bahan bakar, jumlah penumpang yang dapat diangkut, kemudahan dan kenyamanan dalam mengemudi dan sebagainya.

2) Keistimewaan tambahan (features)

Yaitu karakteristik sekunder atau pelengkap, misalnya kelengkapan interior dan eksterior seperti dash board, AC, sound system, door lock system, power steering, dan sebagainya.

3) Keandalan (reliability)

Yaitu kemungkinan kecil akan menga-lami kerusakan atau gagal dipakai, misalnya mobil tidak sering ngadat/macet/rewel/rusak.

Menurut Alma (2007) Produk adalah segala sesuatu yang dapat ditawarkan di pasar, untuk memuaskan kebutu-han dan keinginan konsumen. Produk terdiri dari atas barang, jasa, pengalaman, events, orang, tempat, kepemilikan, organisasi, informasi dan ide.

Jadi produk itu bukan hanya berbentuk sesuatu yang berwujud saja, seperti makanan, pakaian, dan sebagainya, akan tetapi juga sesuatu yang tidak berwujud seperti pelayanan jasa.

Menurut Kristianto ( 2010 ) Kepuasan atau tidak kepuasan pelanggan adalah respon pelanggan terhadap evaluasi ketidaksesuaian (disconfirmation) yang dirasakan antara 
harapan sebelumya (atau norma kinerja lainnya ) dan kinerja aktual produk yang dirasakan setelah pemakaiannya.

Dari defenisi diatas dapat ditarik kesimpulan bahwa pada dasarnya pengertian kepuasan konsumen mencakup perbedaan antara harapan dan kinerja atau hasil yang dirasakan. Kepuasan konsumen diperoleh jika kinerja suatu produk dapat memenuhi atau melebihi harapan konsumen, dan konsumen akan merasa tidak puas jika kinerja suatu produk kurang dari yang diharapkan konsumen.

Menurut Kristianto ( 2010 ) Kepuasan adalah perasaan konsumen setelah membandingkan harapan (pre-purchase expectation) dengan kinerja aktual (actual performance) produk.

Harapan konsumen pada dasarnya sama dengan layanan yang diberikan perusahaan dapat memenuhi keinginan konsumen. Harapan konsumen ditentukan oleh informasi yang diterima dari mulut ke mulut, kebutuhan pribadi, pengalaman dimasa lampau, serta kominikasi eksternal melalui iklan dan promosi. Harapan konsumen kan semakin berkembang seiring dengan berjalanya waktu, semakin banyak informasi yang diterima dan semakin bertambahnya pengalaman konsumen pada kahirnya akan berpengaruh terhadap tingkat kepuasan yang dirasakan konsumen.

\section{METODE}

Dalam penulisan ini, Instrumen pengumpulan data yang penulis lakukan adalah sebagai berikut : 1 . Angket tertutup

Digunakan untuk mengumpulkan data tentang tingkat kepuasaan konsumen/ pelanggan PDAM Tirtabina Rantauprapat Labuhanbatu.

Pengisian angket/ kuesioner diukur dengan menggunakan skala likert yang terdiri atas: sangat setuju, setuju, cukup setuju, tidak setuju, sangat tidak setuju. Kelima penilaian tersebut diberi bobot sebagai berikut :

1. Jawaban sangat setuju diberi bobot 5

2. Jawaban setuju diberi bobot 4

3. Jawaban cukup setujudiberi bobot 3

4. Jawaban tidak setuju diberi bobot 2

5. Jawaban sangat tidak setuju diberi bobot 1

Untuk menenetukan kategori hasil angket kualitas air bersih (X) dan tingkat kepuasan konsumen (Y) dan dapat dihitung dengan menggunakan rumus sebagai berikut: Skor Rata - Rata Angket $=$

\begin{tabular}{llrl} 
Skor & yang & diperoleh & $\begin{array}{r}\text { Responden } \\
\text { x } 100 \% .\end{array}$ \\
\hline
\end{tabular}

Jumlah Responden

Hasil tabulasi dapat di deskripsikan sebagai berikut: 


\section{Tabel 1.1. Interpretasi Hasil Angket}

\begin{tabular}{|c|c|}
\hline Kategori & Nilai \\
\hline Sangat Setuju (SS) & $4,01-5,00$ \\
\hline Setuju (S) & $3,01-4,00$ \\
\hline Cukup Setuju (CS) & $2,01-3,00$ \\
\hline Tidak Setuju (TS) & $1,01-2,00$ \\
\hline $\begin{array}{c}\text { Sangat Tidak Setuju } \\
\text { (STS) }\end{array}$ & $0,00-1,00$ \\
\hline
\end{tabular}

2. Dokumentasi

Penelitian ini dilakukan dengan cara memperoleh laporan dan dokumendokumen lainnya yang erat hubungannya dengan objek penelitian dan membaca literatur-literatur sebagai dasar teori yang akan dijadikan sebagai landasan teoritis.

Teknik analisis yang digunakan dalam memecahkan masalah yang telah dikemukakan serta untuk membuktikan hipotesis adalah :Analisis deskriptif yakni suatu analisis yang menguraikan perkembangan penjualan yang dicapai oleh perusahaan.

\section{Uji Validitas}

Analisis validitas adalah suatu ukuran yang Untuk pengujian dilakukan dengan menggunakan statistik product moment dengan rumus sebagai berikut :

$$
\mathrm{r}_{\underline{N}}^{=} \frac{\sum \mathrm{XY}-\left(\sum \mathrm{X}\right)\left(\sum \mathrm{Y}\right) \quad \mathrm{xy}}{\sqrt{\left\{\mathrm{N} \sum \mathrm{X}^{2}-\left(\sum \mathrm{X}\right)^{2}\right\}\left\{\mathrm{N} \sum \mathrm{Y}^{2}-\left(\sum \mathrm{Y}\right)^{2}\right\}}}
$$

(Arikunto,2008:171)

$\mathrm{r}_{\mathrm{xy}}$ : Koefisien korelasi antara variable $\mathrm{x}$ dan $\mathrm{y} \mathrm{X}$ :

Skor item (jumlah skor)

$Y \quad$ : Skor total responden

$\mathrm{N} \quad$ : Jumlah seluruh responden

Nilai $r$ kemudian dikonsultasikan dengan $r_{\text {tabel }}$ untuk taraf $\square=0,05$. Bila $r_{\text {hitung }}$ dari rumus di atas $>r_{\text {tabel }}$ maka dapat disimpulkan bahwa angket tersebut valid, dan sebaliknya. Setelah didapat harga koefisien validitas maka harga tersebut diinterprestasikan terhadap kriteria dengan mengunakan tolak ukur yang dibuat Guilford (Suherman, 2003: 113) seperti pada Tabel berikut:

Tabel 1.2. Klasifikasi Interpretasi Koefisien Validitas

\begin{tabular}{|l|c|}
\hline Besarrhitung & Interpretasi \\
$0,90 \leq r_{\text {hitung }}$ & Validitas sangat \\
$\leq 1,00$ & tinggi
\end{tabular}




\begin{tabular}{|c|c|}
$0,70 \leq$ rhitung $^{2}$ & Validitas tinggi \\
\hline $0,40 \leq$ & \\
rhitung $<0,70$ & Validitas sedang \\
$0,20 \leq$ & \\
rhitung $<0,40$ & Validitas rendah \\
$0,00 \leq r_{\text {hitung }}<0,20$ & Validitas sangat \\
rhitung $<0,00$ & rendah \\
\hline
\end{tabular}

\section{Uji Reliabilitas}

Dalam menentukan realibilitas angket digunakan rumus Alpha menurut Arikunto (2008:171):

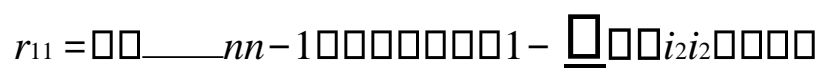

\section{口}

Dimana:

$r_{11}=$ reliabilitas instrumen

$\square \square i^{2}=$ varian butir/item ke-i

$\square i^{2} \quad=$ varian total

$\mathrm{N}=$ Jumlah responden Yang masing-masing

nilai diatas dihitung dengan rumus:

$$
\sigma^{2}=\frac{\sum x^{2}-\left(\sum x\right)^{2}}{N}
$$

Dengan : $\mathrm{x}=$ skor

butir ke-i

$\mathrm{N}$ = banyak responden

Nilai $r$ kemudian dikonsultasikan dengan $r_{\text {tabel }}$ untuk taraf $\square=0,05$. Bila $r_{\text {hitung }}$ dari rumus di atas $>r_{\text {tabel }}$ maka dapat disimpulkan bahwa angket tersebut reliabel, dan sebaliknya. Setelah didapat harga koefisien reliabilitas maka harga tersebut diinterprestasikan terhadap kriteria dengan mengunakan tolak ukur yang dibuat Guilford (Suherman, 2003: 113) seperti pada Tabel berikut:

\section{Tabel 3.5. Klasifikasi Koefisien Reliabilitas}

\section{Besar $r_{11}$}




$\begin{array}{cc}\mathrm{r}_{11} \leq 0,20 & \begin{array}{c}\text { Reliabilitas sangat } \\ \text { rendah }\end{array} \\ 0,20 \leq \mathrm{r}_{11}<0,40 & \text { Reliabilitas rendah } \\ 0,40 \leq \mathrm{r}_{11}<0,70 & \text { Reliabilitas sedang } \\ 0,70 \leq \mathrm{r}_{11}<0,90 & \text { Reliabilitas tinggi } \\ 0,90 \leq \mathrm{r}_{11}<1,00 & \text { Reliabilitas sangat } \\ & \text { tinggi }\end{array}$

Analisis Uji Korelasional untuk mengetahui seberapa besar keterkaitan antara kualitas air bersih terhadap tingkat kepuasan konsumen. Kriteria yang digunakan adalah terdapat korelasi atau hubungan antara variable $\mathrm{X}$ dengan $\mathrm{Y}$ bila $: r_{\text {hitung }}>r_{\text {tabel. }}$ Untuk korelasi ini digunakan korelasi product moment, yaitu :

$\mathrm{r}_{\mathrm{N}} \sum \mathrm{XY}-\left(\sum \mathrm{X}\right)\left(\sum \mathrm{Y}\right)$

$\sqrt{\left\{N \Sigma X^{2}-(\Sigma X)^{2}\right\}\left\{N Y^{2}-(\Sigma Y)^{2}\right\}}$

(Arikunto,2008:171)

Koefisien korelasi antara variable $\mathrm{x}$ dan $\mathrm{y}$

$r_{x y}$ : Koefisien korelasi product moment $\mathrm{X}$

: Angka mentah variable bebas

$Y \quad$ : Angka mentah variable terikat

$\mathrm{N} \quad$ : Banyak sampel

Nilai $r$ kemudian dikonsultasikan dengan $r_{\text {tabel }}$ untuk taraf $\square=0,05$. Bila $r_{\text {hitung }}$ dari rumus di atas $>r_{\text {tabel }}$ maka dapat disimpulkan terdapat hubungan atau korelasi.

Menurut Sugiyono (2007) pedoman untuk memberikan interpretasi koefisien korelasi sebagai berikut:
$0,00-0,199=$ sangat rendah
$0,20-0,399=$ rendah
$0,40-0,599=$ sedang
$0,60-0,799=$ kuat
$0,80-1,000=$ sangat kuat

\section{Pengujian Hipotesis}

Hipotesis dalam penelitian ini adalah "Di duga terdapat hubungan yang signifikan antara kualitas air bersih terhadap tingkat kepuasaan konsumen pada PDAM Tirtabina Rantauprapat Labuhanbatu".

Hipotesis yang akan diuji dalam penelitian ini adalah :

Ho : $\mathrm{C}=0 \quad$ Vs $\quad \mathrm{H}_{1}: \square>0$

Uji hipotesis digunakan uji keberartian $\mathrm{r}$ dengan statistik t yaitu : 


$$
t=\frac{r \sqrt{n-2}}{\sqrt{1-r^{2}}}(\text { Sudjana, 2010: 109). }
$$

dengan $\mathrm{dk}=\mathrm{n}-2$ dan $\mathrm{Q}=0,05$ diterima Ha jika $t_{\text {hitung }}>t(1-1 / 2 \mathrm{Q})$.

Dimana :

$t \quad=$ Harga untuk sampai berkorelasi

$r_{x y}=$ Koefisien korelasi product moment

$\mathrm{N}=$ Jumlah Sampel

\section{Uji Determinasi}

Untuk mengetahui hubungan variabel secara persentase yang digunakan dengan menguji koefisien determinasi dengan menggunakan rumus sebagai berikut:
$\mathrm{D}=r_{x y^{2} \times 100 \%}$
$\mathrm{D}=$ Koefisien Determinasi
$\mathrm{R}=$ Nilai Koefisien Korelasi

\section{HASIL DAN PEMBAHASAN}

\section{Analisis Hasil Penelitian}

Dari data yang diperoleh dilakukan pengujian dengan menggunakan rumus korelasi product moment sebagai berikut:

$$
\begin{array}{ll}
\mathrm{N} & =99 \\
\sum X & =6840 \\
\sum Y & =1267 \\
\sum X^{2} & =477574 \\
\sum Y^{2} & =16457 \\
\sum X Y= & 88217
\end{array}
$$

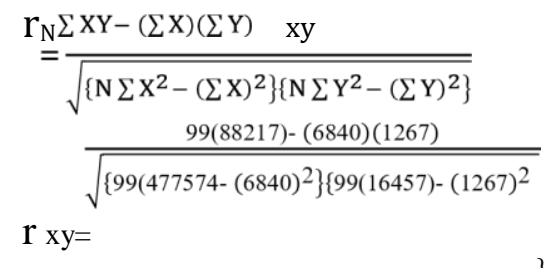

8733483- 8666280

$\mathrm{r} x y=$

$$
\frac{67203}{\sqrt{\{494226\}\{23954\}}}
$$

$\mathrm{r} x \mathrm{y}=$

$$
\begin{aligned}
& r_{x y}= \\
& \quad \frac{67203}{\sqrt{11838689604}} \\
& \quad r_{x y}=r_{x y}= \\
& 0,617
\end{aligned}
$$


Dari hasil perhitungan diatas dapat diketahui bahwa besar koefisien korelasi $r_{x y}$ sebesar 0,617. Nilai $r$ kemudian dikonsultasikan dengan $r_{\text {tabel }}$ untuk taraf $\square=0,05$. Bila $r_{\text {hitung }}$ dari rumus di atas $>r_{\text {tabel }}$ maka dapat disimpulkan terdapat hubungan atau korelasi.Dengan demikian dapat disimpulkan bahwa ada hubungan yang positif antara kualitas air bersih terhadap tingkat kepuasaan konsumen karena $r_{\text {hitung }} 0,617>r_{\text {tabel }} 0,202$. Adapun interpretasi koefisien korelasiantara kualitas air bersih terhadap tingkat kepuasan konsumen berada pada kisaran kuat.

Kemudian untuk mengetahui apakah terdapat hubungan yang signifikan antara kualitas air bersih terhadap tingkat kepuasaan konsumen pada PDAM Tirta Bina Rantauprapat Labuhanbatu maka dilakukan dengan pengujian hipotesis dengan menggunakan Uji keberartian $\mathrm{r}$ dengan statistik t yaitu :

$$
t=\frac{r \sqrt{n-2}}{\sqrt{1-r^{2}}} \text { (Sudjana, 2010: 109). }
$$

dengan $\mathrm{dk}=\mathrm{n}-2$ dan $\mathrm{Q}=0,05$ diterima Ha jika $t_{\text {hitung }}>t(1-1 / 2 \mathrm{Q})$.

Dimana :

$t=$ Harga untuk sampai berkorelasi $r_{x y}=$

Koefisien korelasi product moment

$\mathrm{n} \quad=$ Jumlah Sampel

Adapun perhitungan uji $t$ dengan menggunakan rumus diatas dinyatakan sebagai berikut:

$r_{x y}=0,617$

$\mathrm{n} \quad=99$ maka

$t=\frac{0,617 \sqrt{99-2}}{\sqrt{1-0,617^{2}}}$

$t=\frac{0,617 \sqrt{97}}{\sqrt{1-0,380689}}$

$t=\frac{0,617(9,848858)}{\sqrt{1-0,380689}}$

$t=\frac{6,076745}{\sqrt{0,619311}}$

$t=\frac{6,076745}{0,786963}$

$t=7,721$

Dengan taraf kesalahan $5 \% \mathrm{dk}=\mathrm{n}-2($ diperoleh $99-2=97)$ sedangkan nilai $t_{\text {tabel }}$ 1,660. Dengan demikian dari hasil pengujian hipotesis ternyata $t_{\text {hitung }}>t_{\text {tabel }}$ yaitu $7,721>$ 1,660. Oleh karena itu Ho ditolak dan Ha diterima, sehingga dapat ditarik kesimpulan "terdapat hubungan yang signifikan antara kualitas air bersih terhadap tingkat kepuasaan konsumen pada PDAM Tirta Bina Rantauprapat Labuhanbatu".

Selanjutnya untuk mengetahui seberapa besar persentase hubungan antara kualitas air bersih terhadap tingkat kepuasaan konsumen pada PDAM Tirta Bina Rantauprapat Labuhanbatu dilakukan dengan menguji koefisien determinasi sebagai berikut:

$\mathrm{D}=r_{x y^{2} x 100 \%}$ 


$$
\begin{aligned}
& =(0,617)^{2} \times 100 \% \\
& =0,380689 \times 100 \% \\
& =38,07 \%
\end{aligned}
$$

Nilai diatas menunjukkan bahwa pengaruh variabel $\mathrm{X}$ (kualitas air bersih) terhadap variabel Y (tingkat kepuasan konsumen) sebesar 38,07\% sedangkan sisanya sebesar $61,93 \%(100-38,07)$ dipengaruhi oleh faktor lain. Faktor lain diantaranya adalah kualitas pelayanan karyawan yang baik, pelayanan pasang baru yang mudah, layanan pembayaran yang mudah dengan sistem online dan lain-lain.

\section{KESIMPULAN}

Adapun kesimpulan penelitian ini untuk menjawab rumusan masalah dan membuktikan hipotesis penelitian adalah sebagai berikut:

1. Berdasarkan hasil korelasi product moment diketahui bahwa koefisien korelasi $\left(r_{x y}\right)$ adalah sebesar 0,617. Melihat hasil perhitungan diatas dapat disimpulkan korelasi antara variabel $\mathrm{X}$ (kualitas air bersih) terhadap variabel $\mathrm{Y}$ (tingkat kepuasaan pelanggan) berkorelasi positif. Dan berdasarkan nilai uji $t$, untuk $\mathrm{dk}=97$ adalah $t=$ 7,721. Dari hasil pengujian ternyata $t_{\text {hitung }}>t_{\text {tabel }}$ yaitu 7,721 $>1,660$. Oleh karena itu Ha diterima dan Ho ditolak. Sehingga dapat ditarik kesimpulan "terdapat hubungan yang signifikan antara kualitas air bersih terhadap tingkat kepuasaan konsumen pada PDAM Tirta Bina Rantauprapat Labuhanbatu".

2. Berdasarkan hasil uji $t$ determinasi menunjukkan bahwa pengaruh variabel $X$ (kualitas air bersih) terhadap variabel Y (tingkat kepuasaan pelanggan) sebesar $38,07 \%$ sedangkan sisanya 61,93\% dipengaruhi oleh faktor lain. Faktor lain yang tidak diteliti adalah kualitas palayanan karyawan yang baik, pelayanan pasang baru yang mudah, layanan pembayaran yang mudah dengan sistem online dan lain-lain.

\section{DAFTAR PUSTAKA}

Alma, Buchari. 2007. Manajemen Pema-saran dan Pemasaran Jasa. Bandung: Alfabeta.

Arikunto, Suharsimi. 2008. Prosedur penelitian Suatu Pendekatan Praktik. Jakarta: Rineka Cipta.

Gaspersz, V. 2001. Analisa Untuk Pendekatan Kualitas, Jakarta: PT.Gramedia Pustaka Utama.

Kristianto, Paulus L. 2010. Psikologi Pemasaran. Yogyakarta: CAPS.

Lupiyoadi, Rambat. 2001. Manajemen Pemasaran Jasa. Jakarta: Salemba Empat. 
Mullins, J., Walker, O.C., Boyd, H. W. and Larreche, J.C. 2005. Marketing Management : A Strategic Decision - Making Approach. New York: McGraw - Hill. (http://thesis.binus.ac.id/ doc/ pustaka/2011-1-00468-mn\%20pstk.pdf). Diakses Tanggal 20 September 2016.

Silitonga, PM. 2011. Statistik.Medan: FMIPA Unimed.

Sudjana, Nana. 2010. Metode Statistika. Bandung: Tarsito.

Sugiyono. 2003. Metode Penelitian Pendidikan. Bandung: Alfabeta.

. 2007. StatistikUntuk Penelitian. Bandung: Alfabet.

Suherman, E. (2003). Petunjuk Praktis untuk Melaksanakan Evaluasi Pendidikan Matematika. Bandung: Wijayakusumah.

Sunyoto, Danang. 2013. Teori, Kuesioner dan Analisis Data Untuk Pemasaran dan Perilaku Konsumen. Yogyakarta: Graha Ilmu.

Tjiptono, Fandy. 2008. Strategi Pemasaran. Yogyakarta: Penerbit Andi.

Umar, Husein, 2002. Metode Riset Bisnis, Jakarta: PT.Gramedia Pustaka Utama, 